\title{
ASSESSMENTS AS REGARD OF SERVICE QUALITY OF TOURISTIC CONSUMERS WHO PARTICIPATE IN EQUESTRIAN TREKKING ACTIVITIES: AN APPLICATION IN CORE CAPPADOCIA, TURKEY
}

\author{
Burcu Gülsevil BELBER* \\ Nevşehir Hacı Bektaş Veli University, Faculty of Tourism, Tourism Management, 2000 \\ Evler Mah. Zubeyde Hanim Cad. 50300, Nevsehir, Turkey, e-mail: bbelber@nevsehir.edu.tr \\ Yakup ERDOĞAN \\ Nevşehir Hacı Bektaş Veli University, Faculty of Tourism, Tourism Management, 2000 \\ Evler Mah. Zubeyde Hanim Cad. 5030o, Nevsehir, Turkey, e-mail: yakup-erdogan@outlook.com
}

\begin{abstract}
Citation: Belber B. G., \& Erdoğan Y. (2019). ASSESSMENTS AS REGARD OF SERVICE QUALITY OF TOURISTIC CONSUMERS WHO PARTICIPATE IN EQUESTRIAN TREKKING ACTIVITIES: AN APPLICATION IN CORE CAPPADOCIA, TURKEY. GeoJournal of Tourism and Geosites, 24(1), 74-87. https://doi.org/10.30892/gtg.24107-344
\end{abstract}

\begin{abstract}
In this study, based on the Servqual Scale a questionnaire consisting of 4 sections and 48 questions was applied in order to determine the service quality evaluations of domestic and foreign tourist consumers participating in equestrian trekking activities in Nevşehir. The study was limited to the local and foreign tourists visiting the equestrian trekking enterprises in Nevşehir. The survey was carried out with 350 people and T test ANOVA and LSD analyses were conducted. The findings of the study showed that the average score of domestic and foreign tourist about physical properties is very close to each other and domestic tourists have positive but foreign tourists have negative evaluations on reliability. In terms of willingness, the evaluations of domestic and foreign tourists are quite high. The general evaluations were negative in terms of assurance. In terms of empathy, the evaluations of both domestic and foreign tourists are positive. In addition, the differences between the evaluations of domestic and foreign tourists on the quality of service in terms of their demographic characteristics were examined. The findings of the study will be used in the enterprises performing equestrian trekking activities so the visitors will be more satisfied with the services provided, the satisfaction level and consequently, the number of devoted customers will increase.
\end{abstract}

Key words: Equestrian Trekking, Horse, Touristic Consumer, Service Quality, Nevşehir

\footnotetext{
* Corresponding author
} 
Assessments as Regard of Service Quality of Touristic Consumers Who Participate in Equestrian Trekking Activities: An Application in Core Cappadocia, Turkey

\section{INTRODUCTION}

Horses, from the first ages of history in the life of humankind have served many different purposes. Initially, fed as prey animals, horses have served as an indispensable element in individual and community life through history since people began to recognize and took advantage of their different characteristics (Ünver, 2006, p.10).

In the past, horse riding had a great importance for travel and transportation. Unfortunately, nowadays in the concept of modern tourism with the foundation of space tourism, it cannot find the enough value it deserves. When the literature is reviewed, no studies were found except for the studies of Güngör (2016), Genç \& Şengül (2016) and Tucker \& Emge (2010) which refer to equestrian trekking in Cappadocia which means 'Land of Beautiful Horses' in Persian language. Of these studies, Güngör's work is directly related to the equestrian trekking in the scope of alternative tourism diversity. The other two studies just mention that equestrian trekking was carried out in Cappadocia.

The cultural and scientific values of Anatolia, which has a history of 6000 years of horse and equestrian history, unfortunately, cannot be sustained today in a way that is appropriate to its history. The Turks are the first who discovered horsees on earth and trained them to use in the life of humankind. However, as in many other fields, the ignoring of science in equestrian sport has led to the need for support from European countries in the implementation of equestrian culture. In order to reach the deserved place on the international platform, there is a need to support the equestrian sport, which has been tried to be developed by local facilities with a large number of scientific research (Ünver, 2003, p. 82). Equestrian trekking which is one of the mentioned in many tourism types such as ecotourism (Hacıŏglu \& Avcıkurt, 2011, p.129; Belber, 2018, p.76), rural tourism (Çimen \& Abac1, 2012, p. 3), adventure tourism (Swarbrooke, et al., 2003, p.105), nature tourism (Kiper \& Yllmaz, 2008, p.166), sustainable tourism (Pickel-Chevalier, 2015 p.110-134) and alternative tourism (Oruç, 2004, p.35), has become a recreationally preferred activity thanks to the riding disciplines developed within many years.

The region Cappadocia includes Nevşehir, Aksaray, Niğde, Kırşehir and Kayseri provinces. The region known as Core Cappadocia with the most observable area of the fairy chimneys consists of Uchisar, Göreme, Avanos, Ürgüp, Derinkuyu, Kaymaklı, Ihlara and its surroundings (Ahiler Kalkınma Ajansı ahika.gov.tr, p. 17).

Equestrian trekking is a new and less known form of recreation than other tourism activities. However, it has an increasing growth potential. With the increase of the demand, an increase in the number of enterprises that organized equestrian trekking in the Core Cappadocia region was observed. The fact that the same improvement in service quality was not seen despite the increasing numbers triggered this study. It was thought that improving the quality of service would have a significant impact on both customer satisfaction and increasing the number of incoming tourists. In this context, the study aimed to determine the service quality assessments of the tourists about enterprises in question and suggestions were made in this direction. Thanks to the enterprises that will operate in accordance with the mentioned suggestions, it is believed that the Cappadocia region will benefit both economically and ecologically.

\section{LITERATURE REVIEW}

In recent years, within the scope of touristic product diversification and sustainable tourism, the sector has been into different quest. Equestrian sport is one of the product diversification efforts in tourism (Aydoğdu \& Tanrısever, 2015). Held in the regions where historical and natural beauties are located, daily or several-day excursion programs are called equestrian trekking (Batman \& Eraslan, 2007, p.203). 
Because of attraction, eligibility and satisfactory income, the number of enterprises organizing equestrian trekking in the Cappadocia region, known as the Land of Beautiful Horses, has increased significantly. Due to the increase of entrepreneurs and demands, different studies have been carried out in the literature, which deals with the issue in terms of socio - economic, cultural and service quality.

In a recreational sense, riding has a long history. This background has formed a significant number of different and well-known riding disciplines, such as dressage, jump shows, endurance, equestrian therapies, cross-country, horse races and western style riding (Ollenburg, 2005). Equestrian tourism has ancient roots in travel on horseback while at the same time constituting a thoroughly modern phenomenon which reflects intriguing trends of postindustrial society (Notzke, 2017, p. 3). Today the recreational use of horses is predominant in the industrialised societies.

In societies where the horse is no longer needed for labour, the cultural aspect of breeding, training and the recreational use of horses as a relationship between human and horse becomes even more pronounced (Helgadóttir, 2006). Equestrian tourism, as a form of broadly understood active tourism and a form of qualified tourism, is practised in free time of tourists for the purpose of exploring the country or region (Jasiñski et al., 2006). Horse tourism is the most inclusive term, and refers to any form of tourism where the horse is an element of the tourism experience (Buchmann, 2017).

Outdoor recreation activities such as hiking, walking, paddling, bird watching and horseback riding are key travel motivators, occur in a variety of settings, are intricately linked to the tourism development process, and are often developed by entrepreneurs within the community (Kline et al., 2015). Knowing whether the guest likes to be treated as a customer or as a travelling companion and knowing which method adds more value to the experience of the guest, is important. Therefore, it is interesting that operators in horse-based tourism in Iceland seem to have more interest in horses and the desires of the guests than in running a profitable business (Helgadottir \& Sigurðardottir, 2004).

Equestrian tourism has, in most cases, developed from an operator's passion for horses and is identified as a lifestyle industry; whereas developing a business is defined as a long-term process - including hard work and long working hours - while some operators find it hard to distinguish between their hobby and livelihood (Helgadóttir \& Sigurðardóttir, 2008; Sigurðardóttir, 2015). The development of outdoor riding has also led to it becoming more professional in the field of tourism. First, the FFE created the label 'Equestrian Tourism Center', which aims to give credibility to companies, which link this activity to a high-quality welcome and choice of horses (Pickel-Chevalier, 2015).

The quality of service is the feeling that the customers have after purchasing service and implies whether or not they are satisfied with the service. Therefore, the concept of service quality can be described as the needs and expectations of the customer, the features of the service and the degree of which the service have these characteristics (Özveren, 2010). According to the model developed by Parasuraman, Zeithaml and Berry, service quality is based on the comparison of customer expectations and perceptions. If the expected service is more than the perceived service, the quality of perceived quality will be low. If the expected service is equal to the perceived service, the perceived quality will be satisfactory. If the expected service is lower than the perceived service, the perceived quality will be high, which will ensure that the quality is ideal (Parasuraman et al., 1988). Servqual service quality scale, developed by Parasuraman, Zeithaml and Berry, and frequently used in the literature was used in the study with 5 factors as "Physical Specifications", "Reliability", "Willingness", "Assurance" and "Emphaty" was utilized. 
Assessments as Regard of Service Quality of Touristic Consumers Who Participate in Equestrian Trekking Activities: An Application in Core Cappadocia, Turkey

\section{MATERIALS AND METHODS}

Problem statement of the study is "Are domestic and foreign tourists visiting the enterprises that perform equestrian trekking activities in Nevşehir sufficiently satisfied with the quality of service of these enterprises?" The aim of this study is to determine the evaluations of the quality of service of domestic and foreign tourists attending equestrian trekking activities in Nevşehir. Furthermore, based on the results of the research, it is aimed to make suggestions on what can be done to ensure that the domestic and foreign tourists visiting the enterprises that perform equestrian trekking activities in Nevşehir will be more satisfied with the quality of the services offered by these enterprises.

The hypotheses for the purpose of the research are expressed as follows:

$\mathrm{H}_{1}$ : There is a difference between domestic and foreign tourists in evaluating the service quality of the enterprises where equestrian trekking activities are carried out.

$\mathrm{H}_{2}$ : According to the demographic characteristics of the local tourists, there are differences between the evaluations of the service quality elements of the enterprises where equestrian trekking activities are carried out.

$\mathrm{H}_{3}$ : According to the demographic characteristics of foreign tourists, there is a difference between the evaluations of the service quality elements of the enterprises where equestrian trekking activities are carried out.

The study was limited to the domestic and foreign tourists visiting the equestrian trekking enterprises in Nevşehir between the dates of 01.01.2018-01.09.2018.

The study was collected using face-to-face survey method that one of the primary data collection methods. The previous academic studies related to the evaluation of the service quality were examined and the questions and expressions to be used in the research were formed. Parasuraman, Zeithaml and Berry (1988, p. 39-40)'s studies and questionnaires were evaluated within the scope of the study and the scale was adapted for the study. The questionnaire used in the research consists of two parts. In the first part, there are questions about the demographic characteristics of the participants and in the second part there are 24 expressions about the quality of service. These statements are rated as "1: Strongly Disagree... 5: Strongly Agree".

The data obtained from the collected questionnaire forms were analyzed by SPSS (Statistical Package for Social Sciences) for Windows 23.0. In order to evaluate the questions about demographic characteristics, frequency distributions were examined. Likert-scale expressions were grouped according to service quality assessment dimensions in the studies of Parasuraman, Zeithaml and Berry (1988, p.23) averages were taken. Then, ANOVA analysis and $T$ test were used for the demographic characteristics of the participants. The results were interpreted and recommendations were made.

In this study, Nevssehir was chosen as the application area in order to obtain suitable data. The population of the research is composed of domestic and foreign tourists visiting the enterprises that carry out equestrian trekking in Nevşehir by September 2018. In order to determine the average number of domestic and foreign tourists who are interested in equestrian trekking in Nevssehir, operating on equestrian trekking enterprises were interviewed face to face. All of these enterprises gave information about their average number of tourists per year. Within the framework of this information, it is determined that about 1200 tourists visited the enterprises for equestrian trekking. At this point, because of the cost, time constraints and unwillingness of people to answer questionnaires, it was preferred to choose a sample to represent the population. As a sampling method, the nonprobability sampling method was used. The aim of this method is to include anyone who wants to participate in the sample (Gürbüz \& Şahin, 2015, p. 130).

The number of samples was calculated by the following formula (Yamane, 2001, 116-117): 
$\mathrm{N}$ : population size

$$
n=\frac{N \cdot z^{2} \cdot p \cdot q}{(N-1) \cdot d^{2}+z^{2} \cdot p \cdot q}
$$

$\mathrm{n}$ : sample size

z: standard normal distribution table value for the desired reliability level

$\mathrm{d}$ : degree of accuracy

$\mathrm{p}$ : the proportion of individuals with the desired feature in the population $(\mathrm{p}+\mathrm{q}=1)$

$$
n=\frac{1200 \cdot 1,96^{2} \cdot 0,5 \cdot 0,5}{(1200-1) \cdot 0,05^{2}+1,96^{2} \cdot 0,5,0,5}=\frac{1152,48}{3,9579931_{a}, 7079}=291,18=291
$$

Due to the possibility of incorrect and incomplete answers to the questionnaires, more questionnaires were applied than the number calculated by the formula.

Because of the survey conducted with randomly selected 350 people from the population of the study, inconsistent and incomplete questionnaires were removed and the remaining 323 questionnaires were analysed.

\section{RESULTS}

The difference between service quality assessments of domestic and foreign tourists was determined by taking the means of service quality assessment and T-Test and ANOVA analyses were used to determine whether there is a significant difference between them in terms of their demographic characteristics. LSD analysis was used to determine which variables caused the differences. To examine whether the data set used in the study shows normal distribution or not, standard deviation has been tested with the values of skewness, kurtosis and it is shown in Table 1 . The standard deviation of a normally distributed data set is expected to be close to 1 , and the skewness and kurtosis values are expected to be between -1 and +1 (Gürbüz \& Şahin, 2015, p. 207-208).

At the end of the analyse, the kurtosis and skewness values were between -1 and +1 and the standard deviation was close to 1 . In addition, "interval scales" are the rating scales which subjective properties are measured. The distance is normally defined as one scale unit for adjacent levels. For example, "a coffee brand rated 3 in taste" is one unit away from "a coffee brand which rated 4". In this case, equal intervals exist between the level descriptors (Burns \& Bush, 2014, 177-179). For these reasons, ANOVA analysis and T test were used from parametric tests in this study.

Table 1. Normality Distribution

\begin{tabular}{|l|c|c|c|}
\hline Evaluation Elements of Service Quality & Standard Deviation & Skewness & Kurtosis \\
\hline Physical Specifications &, 64732 &,- 469 &, 437 \\
\hline Reliability &, 84651 &,- 861 &, 392 \\
\hline Willingness &, 81691 &,- 885 &, 397 \\
\hline Assurance &, 68267 &, 093 &,- 685 \\
\hline Empathy &, 78533 &,- 731 &,- 161 \\
\hline
\end{tabular}

Table 2. Reliability Test

\begin{tabular}{|l|c|c|}
\hline \multicolumn{2}{|c|}{ Kaiser-Meyer-Olkin Measure of Sampling Adequacy } &, 867 \\
\hline \multirow{3}{*}{ Bartlett's Test of Sphericity } & Approx. Chi-Square & 3909,405 \\
\cline { 2 - 3 } & df & 276 \\
\cline { 2 - 3 } & Sig. &, ooo \\
\hline
\end{tabular}


Assessments as Regard of Service Quality of Touristic Consumers Who Participate in Equestrian Trekking Activities: An Application in Core Cappadocia, Turkey

In order to measure the reliability of the scale used in the study, reliability analysis was performed and is shown in Table 2 .

The reliability coefficient should be 0.70 and above (Cronbach Alpha $(0.70)<x$ ) (Gürbüz \& Şahin, 2015, p. 317). The reliability coefficient of the scale was estimated as (Cronbach Alpha) o,867 and was interpretted to have a valid reliability level. Table 3 shows the demographic distributions of domestic and foreign tourists.

Table 3. Demographic Distribution of Domestic and Foreign Tourists

\begin{tabular}{|c|c|c|c|c|c|c|}
\hline \multicolumn{4}{|c|}{ Domestic Tourists } & \multicolumn{3}{|c|}{ Foreign Tourists } \\
\hline & $\mathrm{f}$ & $\%$ & \multirow{3}{*}{ Gender } & & $\mathrm{f}$ & $\%$ \\
\hline Male & 91 & 52,9 & & Male & 74 & 49 \\
\hline Female & 81 & 47,1 & & Female & 77 & 51 \\
\hline $15-25$ & 46 & 26,7 & \multirow{5}{*}{ Age } & $15-25$ & 28 & 18,5 \\
\hline 26-35 & 68 & $\mathbf{3 9 , 5}$ & & 26-35 & 78 & 51,7 \\
\hline $36-45$ & 33 & 19,2 & & $36-45$ & 34 & 22,5 \\
\hline 46-55 & 16 & 9,3 & & $46-55$ & 7 & 4,6 \\
\hline 56 and older & 9 & 5,2 & & 56 and older & 4 & 2,6 \\
\hline Single & 106 & 61,6 & \multirow{2}{*}{ Marital Status } & Single & 94 & 62,3 \\
\hline Married & 66 & 38,4 & & Married & 57 & 37,7 \\
\hline 0 & 111 & 64,5 & \multirow{5}{*}{ Number of Children } & 0 & 95 & 62,9 \\
\hline 1 & 24 & 14 & & 1 & 25 & 16,6 \\
\hline 2 & 17 & 9,9 & & 2 & 22 & 14,6 \\
\hline 3 & 15 & 8,7 & & 3 & 8 & 5,3 \\
\hline 4 or above & 5 & 2,9 & & 4 or above & 1 & 0,7 \\
\hline Primary School & 6 & 3,5 & \multirow{4}{*}{ Education Level } & Primary School & 2 & 1,3 \\
\hline High School & 54 & 31,4 & & High School & 22 & 14,6 \\
\hline Undergraduate & 90 & 52,3 & & Undergraduate & 109 & 72,2 \\
\hline Postgraduate & 22 & 12,8 & & Postgraduate & 18 & 11,9 \\
\hline Worker & 47 & 27,3 & \multirow{8}{*}{ Occupation } & Worker & 42 & 27,8 \\
\hline Civil Servant & 36 & 20,9 & & Civil Servant & 42 & 27,8 \\
\hline Retired & 12 & 7 & & Retired & 5 & 3,3 \\
\hline Student & 39 & 22,7 & & Student & 35 & 23,2 \\
\hline University & 8 & 4,7 & & University Teacher & 7 & 4,6 \\
\hline Tradesman & 12 & 7 & & Tradesman & 13 & 8,6 \\
\hline Housewife & 9 & 5,2 & & Housewife & 4 & 2,6 \\
\hline Others & 9 & 5,2 & & Others & 3 & 2 \\
\hline Less than & 52 & 30,2 & \multirow{6}{*}{ Monthly Income } & Less than $2000 \$$ & 36 & 23,8 \\
\hline 2000-3000TL & 59 & 34,3 & & $2000-3000 \$$ & 48 & 31,8 \\
\hline 3001-4000 TL & 42 & 24,4 & & $3001-4000 \$$ & 48 & 31,8 \\
\hline 4001-5000TL & 12 & 7 & & $4001-5000 \$$ & 16 & 10,6 \\
\hline 5001-600oTL & 7 & 4,1 & & $5001-6000 \$$ & 3 & 2 \\
\hline Total & 172 & 100 & & Total & 151 & 100 \\
\hline
\end{tabular}

The majority of the domestic tourists (52.9\%) are male and the foreign tourists (51.9\%) are female. The majority of domestic tourists (39.5\%) and foreign tourists (51.7\%) are between 26 and 35 years old. The majority of domestic tourists (61.6\%) and foreign tourists (62.3\%) are single. The majority of the domestic tourists $(64.5 \%)$ and foreign tourists $(62.9 \%)$ do not have children. Domestic $(52.3 \%)$ and foreign tourists $(72.2 \%)$ are 
undergraduates. The majority of the domestic tourists are workers (27.3\%), the majority of foreign tourists are workers (27.8\%) and civil servants (27.8\%). For the determination of monthly income; In the questionnaire forms TL and $\$$ options are used for domestic and foreign tourists, respectively. The majority of the domestic tourists have income between 2000-3000TL (34.3\%) and the majority of foreign tourists have income between 2000$4000 \$(63.6 \%)$. Table 4 shows the distribution of local and foreign tourists by region.

Table 4. Residence of Domestic and Foreign Tourists

\begin{tabular}{|c|c|c|c|c|c|c|}
\hline \multicolumn{3}{|c|}{ Domestic Tourists } & \multirow{10}{*}{ Residence } & \multicolumn{3}{|c|}{ Foreign Tourists } \\
\hline Regions & $\mathrm{f}$ & $\%$ & & Continents & $f$ & $\%$ \\
\hline Central Anatolia & 60 & 34,9 & & \multirow{2}{*}{ Europe } & \multirow[b]{2}{*}{63} & \multirow{2}{*}{41,7} \\
\hline Aegean & 34 & 19,8 & & & & \\
\hline Mediterranean & 28 & 16,3 & & \multirow{2}{*}{ Asia } & \multirow{2}{*}{55} & \multirow{2}{*}{36,4} \\
\hline Marmara & 18 & 10,5 & & & & \\
\hline The Blacksea & 11 & 6,4 & & \multirow{2}{*}{ America } & \multirow[b]{2}{*}{33} & \multirow[b]{2}{*}{21,9} \\
\hline SoutheasternAnatolia & 11 & 6,4 & & & & \\
\hline Eastern Anatolia & 10 & 5,7 & & \multirow{2}{*}{ Total } & \multirow[b]{2}{*}{151} & \multirow{2}{*}{100} \\
\hline Total & 172 & 100 & & & & \\
\hline
\end{tabular}

When Table 4 is examined; domestic tourists are mostly from Central Anatolia (34.9\%), Aegean (19.8\%) and Mediterranean (16.3\%) regions, and foreign tourists are from Europe (41.7\%) and Asia (36.4\%).

Table 5. Evaluations and Means of Service Quality Elements of Domestic and Foreign Tourists

\begin{tabular}{|c|c|c|c|c|c|}
\hline $\begin{array}{c}\text { Evaluation Elements } \\
\text { of Service Quality }\end{array}$ & Expressions & \multicolumn{2}{|c|}{$\begin{array}{c}\text { Means of } \\
\text { Domestic Tourists }\end{array}$} & \multicolumn{2}{|c|}{$\begin{array}{c}\text { Means of } \\
\text { Foreign Tourists }\end{array}$} \\
\hline \multirow{6}{*}{$\begin{array}{c}\text { Physical } \\
\text { Specifications }\end{array}$} & $\begin{array}{l}\text { There are suitable horses for riders of } \\
\text { different ages. }\end{array}$ & 2,8488 & \multirow{6}{*}{3,1240} & 2,4901 & \multirow{6}{*}{3,1148} \\
\hline & $\begin{array}{l}\text { There are suitable horses for riders of } \\
\text { different riding levels. }\end{array}$ & 2,8430 & & 2,5232 & \\
\hline & $\begin{array}{l}\text { Instructors (trainers) and side walkers } \\
\text { are presentable. }\end{array}$ & 4,1802 & & 4,1589 & \\
\hline & Horses are sleek. & 3,0349 & & 2,8477 & \\
\hline & $\begin{array}{l}\text { Physical environment is satisfactory } \\
\text { (restroom, protective materials for } \\
\text { riders' safety etc.). }\end{array}$ & 1,9186 & & 2,8477 & \\
\hline & $\begin{array}{l}\text { Behaviors of other customers are } \\
\text { suitable to the ambience. }\end{array}$ & 3,9186 & & 3,8212 & \\
\hline \multirow{4}{*}{ Reliability } & The number of horses is enough. & 3,3968 & \multirow{4}{*}{3,1450} & 3,2416 & \multirow{4}{*}{ 2,4455 } \\
\hline & Tour route is safe. & 3,7199 & & 3,2597 & \\
\hline & $\begin{array}{l}\text { The staff gives informative instructions } \\
\text { to riders sufficiently. }\end{array}$ & 3,9868 & & 2,1489 & \\
\hline & Insurance services for activities are enough. & 1,4768 & & 1,1721 & \\
\hline \multirow{4}{*}{ Willingness } & $\begin{array}{l}\text { The number of instructors and side } \\
\text { walker is enough. }\end{array}$ & 3,5668 & \multirow{4}{*}{3,6328} & 3,9819 & \multirow{4}{*}{4,1262} \\
\hline & Waiting time is short for horse-riding trip. & 2,6742 & & 3,9801 & \\
\hline & $\begin{array}{l}\text { Attitudes and behaviors of employees } \\
\text { are satisfactory. }\end{array}$ & 4,1228 & & 4,3525 & \\
\hline & The staff is polite to the riders. & 4,1674 & & 4,1904 & \\
\hline
\end{tabular}


Assessments as Regard of Service Quality of Touristic Consumers Who Participate in Equestrian Trekking Activities: An Application in Core Cappadocia, Turkey

\begin{tabular}{|c|c|c|c|c|c|}
\hline \multirow{4}{*}{ Assurance } & $\begin{array}{l}\text { Horse equipment (saddle, bridle, rein, } \\
\text { etc) is in good condition. }\end{array}$ & 3 & \multirow{4}{*}{2,4507} & 2,6425 & \multirow{4}{*}{2,3765} \\
\hline & Horses are quiet. & 3,2305 & & 3,3311 & \\
\hline & First aid facilities are enough. & 2,0123 & & 2,1121 & \\
\hline & $\begin{array}{l}\text { Business certifications and staffs certifications } \\
\text { are in a place that everyone can see. }\end{array}$ & 1,5602 & & 1,4205 & \\
\hline \multirow{6}{*}{ Empathy } & Price and service quality is consistent. & 3,0165 & \multirow{6}{*}{3,2239} & 4,3728 & \multirow{6}{*}{3,6185} \\
\hline & $\begin{array}{l}\text { The prices of other goods and services } \\
\text { (food \& beverage, souvenirs etc.) are } \\
\text { satisfactory, too. }\end{array}$ & 3,0491 & & 4,0020 & \\
\hline & $\begin{array}{l}\text { Registration desk, lobby and food \& } \\
\text { beverage services are enough. }\end{array}$ & 3,4244 & & 3,4238 & \\
\hline & Parking area is enough. & 4,0116 & & 4,2649 & \\
\hline & Transportation is easy. & 4,2093 & & 4,2914 & \\
\hline & There are disabled facilities. & 1,6325 & & 1,3563 & \\
\hline
\end{tabular}

The expressions used in the evaluation of the service quality and the elements formed by these expressions and the average of these elements are shown in Table 5 . When Table 5 is examined, both domestic and foreign tourists' views on physical properties are positive, domestic tourists are more positive about reliability, foreign tourists are more positive about their willingness, assurance in both groups is negative of foreign tourists were more positive in terms of empathy.

ANOVA analysis and T test were used to determine the differences between the evaluations, in terms of the demographic characteristics of the quality of service of domestic and foreign tourists. According to ANOVA analysis and T test results, no difference was found between domestic and foreign tourists in terms of gender, marital status, age and number of children. In terms of educational level of domestic tourists, there is no difference. However, there is a difference for foreign tourists.

Table 6. Differences Among Foreign Tourists' Assessment of Service Quality Elements in terms of Their Educational Levels

\begin{tabular}{|c|c|c|c|c|c|c|c|}
\hline $\begin{array}{l}\text { Evaluation Elements } \\
\text { of Service Quality }\end{array}$ & \multicolumn{2}{|c|}{ Education Levels } & $\begin{array}{c}\text { Mean } \\
\text { Difference }\end{array}$ & $\begin{array}{l}\text { Standard } \\
\text { Error }\end{array}$ & df & $\mathrm{F}$ & Sig. \\
\hline \multirow{2}{*}{ Willingness } & Underorad & Primary School & $-1,35436$ &, 51076 & \multirow{2}{*}{3} & \multirow{2}{*}{8,88} & \multirow{2}{*}{, ,oo0 } \\
\hline & Undergrad & High School &,- 72936 & , 16730 & & & \\
\hline \multirow{4}{*}{ Empathy } & & Primary School & $-1,35474$ & ,46259 & \multirow{4}{*}{3} & \multirow{4}{*}{7,276} & \multirow{4}{*}{, OO } \\
\hline & Unde & High School &,- 52898 & ,15152 & & & \\
\hline & \multirow{2}{*}{ Postgraduate } & Primary School & $-1,00926$ &, 48320 & & & \\
\hline & & High School &,- 87446 & 13091 & & & \\
\hline
\end{tabular}

When Table 6 is examined, according to their educational status of foreign tourists there are differences about willingness and emphaty. The average scores of primary and high school graduates for willingness is higher than the average scores of undergraduate. For empathy, the average scores of primary and high school graduates is higher than those of undergraduate and postgraduates. When Table 7 is examined, there is a difference between tradesmen and civil servants, students, university teachers and housewives for willingness. For empathy; differences were found between workers and civil servants, retirees, students, university teachers and tradesmen.

When Table 8 is examined, for assurance there are differences between workers and civil servants and university teachers; between students and civil servants and university 
teachers; between housewives and civil servants and university teachers in the element of assurance. For empathy; there is a difference between civil servants and workers and students; between retirees and workers; between university teachers and workers, students and housewives; between tradesmen and workers.

Table 7. Differences among Domestic Tourists' Assessment

of Service Quality Elements in terms of Their Occupations

\begin{tabular}{|c|c|c|c|c|c|c|c|}
\hline $\begin{array}{l}\text { Evaluation Elements } \\
\text { of Service Quality }\end{array}$ & & cupation & $\begin{array}{c}\text { Mean } \\
\text { Difference }\end{array}$ & $\begin{array}{l}\text { Standard } \\
\text { Error }\end{array}$ & $\mathrm{df}$ & $\mathrm{F}$ & $\mathrm{p}$ \\
\hline \multirow{4}{*}{ Willingness } & \multirow{4}{*}{ Tradesman } & Civil Servant &,- 54167 &, 27076 & \multirow{4}{*}{7} & \multirow{4}{*}{2,882} & \multirow{4}{*}{, 007} \\
\hline & & Student & -.75160 &, 26814 & & & \\
\hline & & University Teacher &,- 75000 &, 37075 & & & \\
\hline & & Housewife &,- 96528 & ,35818 & & & \\
\hline \multirow{5}{*}{ Empathy } & \multirow{5}{*}{ Worker } & Civil Servant &,- 70144 & , 17648 & \multirow{5}{*}{7} & & \multirow{5}{*}{,000 } \\
\hline & & Retired & $-1,08570$ & ,25771 & & \multirow{4}{*}{4,566} & \\
\hline & & Student &,- 57501 & 17259 & & & \\
\hline & & University Teacher &,- 65514 & ,30475 & & & \\
\hline & & Tradesman &,- 76625 & 25771 & & & \\
\hline
\end{tabular}

Table 8. Differences Among Foreign Tourists' Assessment of Service Quality Elements in terms of Their Occupations

\begin{tabular}{|c|c|c|c|c|c|c|c|}
\hline $\begin{array}{l}\text { Evaluation Elements } \\
\text { of Service Quality }\end{array}$ & \multicolumn{2}{|c|}{ Occupation } & $\begin{array}{c}\text { Mean } \\
\text { Difference }\end{array}$ & $\begin{array}{l}\text { Standard } \\
\text { Error }\end{array}$ & $\mathrm{df}$ & $\mathrm{F}$ & $\mathrm{p}$ \\
\hline \multirow{6}{*}{ Assurance } & \multirow{2}{*}{ Worker } & Civil Servant & ,60000 & , 14563 & \multirow{11}{*}{7} & \multirow{13}{*}{4,737} & \multirow{13}{*}{, 000} \\
\hline & & University Teacher & 68095 & 27245 & & & \\
\hline & \multirow{2}{*}{ Student } & Civil Servant & ,66762 & ,15274 & & & \\
\hline & & University Teacher & ,74857 & ,27631 & & & \\
\hline & \multirow{2}{*}{ Housewife } & Civil Servant & 87619 & ,34920 & & & \\
\hline & & University Teacher & ,95714 & , 41829 & & & \\
\hline \multirow{7}{*}{ Empathy } & \multirow{2}{*}{ Civil Servant } & Worker &, 64683 & ,13839 & & & \\
\hline & & Student & ,38651 & , 14515 & & & \\
\hline & Retired & Worker & ,65079 & ,30003 & & & \\
\hline & & Worker & ,93651 & ,25891 & & & \\
\hline & University & Student & ,67619 & ,26258 & & & \\
\hline & & Housewife & ,91071 & ,39750 & & & \\
\hline & Tradesman & Worker &, 56105 & ,20128 & & & \\
\hline
\end{tabular}

When Table 9 is examined, for assurance there is a difference between domestic tourists with an income of 4001-5000 TL and those with lower income. For empaty, there is a difference between domestic tourists with an income of 3001-4000TL and those with lower income. When Table 10 is examined, for assurance, there is a difference between foreign tourists with an income of $\$ 2,000$ and less and those with an income of 2000-3000 $\$$ and 3001-4000 $\$$. When Table 11 is examined, for assurance, there is a difference between tourists coming from the Black Sea and tourists from Mediterranean, Central Anatolia, Aegean and South Eastern Anatolia; and tourists coming from the Eastern Anatolia and tourists from Mediterranean. For empaty, there is a difference between the tourists coming from Mediterranean and tourists from Marmara and Black Sea and between the tourists coming from Eastern Anatolia and the tourists from Mediterranean, Central Anatolia, Aegean and Southeast Anatolia. When Table 12 is examined, for assurance and empathy, there is a difference between tourists coming from America and tourists from Europe and Asia. 
Assessments as Regard of Service Quality of Touristic Consumers Who Participate in Equestrian Trekking Activities: An Application in Core Cappadocia, Turkey

Table 9. Differences among Domestic Tourists' Assessment of Service Quality Elements in terms of Their Monthly Income

\begin{tabular}{|c|c|c|c|c|c|c|c|}
\hline $\begin{array}{l}\text { Evaluation Elements } \\
\text { of Service Quality }\end{array}$ & \multicolumn{2}{|c|}{ Monthly Income } & \begin{tabular}{|c|} 
Mean \\
Difference
\end{tabular} & $\begin{array}{l}\text { Standard } \\
\text { Error }\end{array}$ & $\mathrm{df}$ & $\mathrm{F}$ & $\mathrm{p}$ \\
\hline \multirow{3}{*}{ Assurance } & \multirow{3}{*}{ 4001-5000 TL } & Less than 2000TL &,- 30641 & , 13146 & \multirow{3}{*}{4} & \multirow{3}{*}{2,828} & \multirow{3}{*}{, 026} \\
\hline & & 2000-3000TL &,- 27740 & 12793 & & & \\
\hline & & 3001-4000TL &,- 53333 & ,20742 & & & \\
\hline \multirow[b]{2}{*}{ Empathy } & \multirow[b]{2}{*}{$3001-4000 \mathrm{TL}$} & \multirow{2}{*}{$\begin{array}{l}\text { Less than 2000TL } \\
2000-3000 \mathrm{TL}\end{array}$} &,- 47466 & ,17260 & \multirow[b]{2}{*}{4} & \multirow[b]{2}{*}{3,187} & \multirow[b]{2}{*}{, 015} \\
\hline & & & -.55724 & 16796 & & & \\
\hline
\end{tabular}

Table 10. Differences among Foreign Tourists' Assessment of Service Quality Elements in terms of Their Monthly Income

\begin{tabular}{|c|c|c|c|c|c|c|c|}
\hline $\begin{array}{c}\text { Evaluation Elements } \\
\text { of Service Quality }\end{array}$ & \multicolumn{2}{|c|}{ Monthly Income } & $\begin{array}{c}\text { Mean } \\
\text { Difference }\end{array}$ & $\begin{array}{c}\text { Standard } \\
\text { Error }\end{array}$ & df & F & $\mathrm{p}$ \\
\hline \multirow{2}{*}{ Assurance } & Less than 2000\$ & $2000-3000 \$$ &, 47778 &, 15314 & \multirow{2}{*}{4,157} & ,003 \\
\cline { 3 - 6 } & & $3001-4000 \$$ &, 56111 &, 15314 & &
\end{tabular}

Table 11. Differences among Domestic Tourists' Assessment of Service Quality Elements in terms of Their Residence

\begin{tabular}{|c|c|c|c|c|c|c|c|}
\hline $\begin{array}{l}\text { Evaluation Elements } \\
\text { of Service Quality }\end{array}$ & \multicolumn{2}{|c|}{ Residence } & $\begin{array}{c}\text { Mean } \\
\text { Difference }\end{array}$ & $\begin{array}{l}\text { Standard } \\
\text { Error }\end{array}$ & $\mathrm{df}$ & Sig & $\mathrm{F}$ \\
\hline \multirow{5}{*}{ Assurance } & \multirow{4}{*}{ The Blacksea } & Mediterranean & 69740 & 22519 & \multirow{5}{*}{6} & \multirow{5}{*}{2,297} & \multirow{5}{*}{,037 } \\
\hline & & Central Anatolia & 46788 & 20757 & & & \\
\hline & & Aegean & 50749 & ,21952 & & & \\
\hline & & Southeastern Anatolia & ,63636 & 26985 & & & \\
\hline & East Anatolia & Mediterranean &, 58286 & ,23314 & & & \\
\hline \multirow{6}{*}{ Empathy } & Mediterranean & Marmara Region &, 55026 & ,25024 & \multirow{6}{*}{6} & \multirow{6}{*}{2,722} & \multirow{6}{*}{,015 } \\
\hline & Neaiterranean & Black Sea & ,60498 & ,29475 & & & \\
\hline & \multirow{4}{*}{ East Anatolia } & Mediterranean & ,97619 & ,30515 & & & \\
\hline & & Central Anatolia & ,85556 & ,28292 & & & \\
\hline & & Aegean & ,77941 & 29798 & & & \\
\hline & & Southeastern Anatolia & 81061 & ,36192 & & & \\
\hline
\end{tabular}

Table 12. Differences among Foreign Tourists' Assessment of Service Quality Elements in terms of Their Residence

\begin{tabular}{|c|c|c|c|c|c|c|c|}
\hline $\begin{array}{c}\text { Evaluation Elements } \\
\text { of Service Quality }\end{array}$ & Resi & & $\begin{array}{c}\text { Mean } \\
\text { Difference } \\
\end{array}$ & $\begin{array}{l}\text { Standard } \\
\text { Error }\end{array}$ & $\mathrm{df}$ & $\mathrm{F}$ & Sig. \\
\hline \multirow{2}{*}{ Assurance } & \multirow{2}{*}{ America } & Europe & ,40317 & ,15242 & \multirow{4}{*}{2} & \multirow{4}{*}{3,966} & \multirow{4}{*}{,021 } \\
\hline & & Asian & ,38061 & ,15619 & & & \\
\hline \multirow{2}{*}{ Empathy } & \multirow{2}{*}{ America } & Europe &, 52886 & , 14176 & & & \\
\hline & & Asian & ,46566 & , 14526 & & & \\
\hline
\end{tabular}

\section{CONCLUSION}

The study examined whether or not domestic and foreign tourists visiting the enterprises performing equestrian trekking activities are sufficiently satisfied with the service quality of these enterprises. In addition, based on the results of the research, it was aimed to make suggestions about what can be done to ensure that the domestic and foreign tourists visiting the enterprises that carry out equestrian trekking activities in Nevşehir will be more satisfied with the quality of the services offered by these enterprises. The scope of 
the study was composed of 323 domestic and foreign tourists visiting the enterprises engaged in equestrian trekking in Nevşehir. Means scores were compered to determine whether there is any difference between domestic and foreign tourists in the evaluation of the service quality of the enterprises where equestrian trekking activities are performed. $\mathrm{T}$ test and ANOVA analysis were used to determine whether there is any difference between the evaluations of the service quality elements in terms of demographic characteristics of domestic and foreign tourists. LSD analysis was used to determine which variables caused differences. When the differences between "service quality assessments of domestic and foreign tourists are examined;

- It was observed that the averages of domestic and foreign tourists were very close to each other in terms of physical properties. Considering the expressions of physical features, because expressions of characteristics do not vary from person to person, it is thought that there is no difference between domestic and foreign tourists. The average value above 3 shows that tourists find businesses satisfactory in terms of physical properties. Therefore, the continuation of such practices would be beneficial for customer satisfaction.

- It has been determined that the evaluations of the domestic tourists in terms of reliability are in a positive way while the evaluations of the foreign tourists are in a negative way. It is seen that the average of the foreign tourists' expressions is very low, especially in terms of insurance and informative instructions. Regarding informative instructions, foreign language knowledge of employees is thought to be insufficient. Therefore, it is clear that care should be taken to ensure that insurance is provided for services and that foreign language knowledge of employees should be increased.

- The evaluations of domestic and foreign tourists about willingness are quite high, however, it was observed that the evaluations of foreign tourists were more positive. The reason for this difference is thought to be more care for foreign tourists by enterprises. Although the positive situation of the enterprises continues, it is thought that providing equal and high quality service without making any distinction between domestic and foreign tourisrts will give more results that are positive.

- It was observed that the general evaluations of the two groups about assurance are negative. However, when the averages of the statements are examined, it is found that the average of horse equipment materials and horses being quiet in nature were very high and the averages of the first aid and operating certificates were quite low. These statements are also caused by the decrease in the general average. Therefore, it is considered that the establishment of the enterprises' documents at the points that everyone can see and increasing the facilities for first aid will bring positive results in the service quality evaluations.

- In terms of empathy, the evaluations of domestic and foreign tourists were positive but the evaluations of foreign tourists were found to be more positive. When the expressions of empathy are examined, it is seen that the averages of the two expressions related to pricing are significantly different between the domestic and foreign tourists. Therefore, this difference is thought to be caused by the gap in monthly income. Although it is not possible to reduce prices according to domestic tourists, it may be beneficial to apply campaign prices in low season as in accommodation facilities. The averages of facilities for disabled people were very low in two tourist groups. In face-to-face interviews with enterprises, it is learned that there were no facilities in many enterprises. These arrangements are important in terms of both ethics and business success.

ANOVA analysis and T-test were conducted in order to determine the differences between the evaluations of the domestic and foreign tourists according to their 
Assessments as Regard of Service Quality of Touristic Consumers Who Participate in Equestrian Trekking Activities: An Application in Core Cappadocia, Turkey

demographic characteristics. The level of education affects people's knowledge of their environment and the outside world, expectations and issues of interest (Rızaoğlu, 2003, p. 139). While there was no difference between the domestic tourists in the study about education, there was a difference in willingness and empathy among foreign tourists. The average of primary and high school graduates about willingness is higher than the average of undergraduates; For empathy, it was determined that the average of primary and high school graduates was higher than those of undergraduates and postgraduates. This difference may stem from the fact that people's expectations increased as their education levels increased. Therefore, it may be possible to say that their evaluations are more negative than tourists with low education level.

In order to change this situation, the service quality should be increased. In the analysis made on domestic tourists in relation to the occupation; for willingness, there was a difference between tradesmen and civil servants, students, university teachers and housewives; for empathy, there was a difference between workers and civil servants, retirees, students, university teachers and tradesmen. In the analysis made on foreign tourists, for assurance, the difference was seen between workers and civil servants and university teachers. Between students and civil servants and university teachers, between housewives and civil servants and university teachers. For empathy, it was seen that there was a difference between workers and students, between university teachers and workers, between university teachers and workers and students and housewives, and between tradesmen and workers. Occupations, life styles, types of products and services they will buy (Meydan Uygur, 2007, p. 174; Rızaoğlu, 2003, p. 139) affect the quality assessment of the services purchased. In the analysis on monthly income of domestic tourists; it is determined that there is a difference between tourists who have an income of 40015000TL and others with the lower income for assurance. For empathy, there was a difference between those with income of 3001-4000TL and those with lower income. For assurance of foreign tourists, there is a difference between tourists who hhave an income of less than \$2000 and those with an income of both \$2001 -3000 and \$3001 -4000.

It is normal for consumers with different levels of income to have different service quality expectations and assessments. It is natural that high-income tourists have higher expectations when considering the possibility of more equestrian trekking activities compared to low-income tourists. In this context, it is possible to say that providing services according to income levels and service quality expectations of the incoming tourists will increase their satisfaction levels.

The country or region of residence affects the attitudes and behaviours of consumers (Swarbrooke \& Horner, 2004, p. 143). When the differences between the domestic tourists in terms of service quality are examined according to their residence; for assurance, the differences are observed between tourists coming from the Black Sea and those coming from the Mediterranean, Central Anatolia, the Aegean and Southeastern between tourists from the Eastern Anatolia and those coming from the Mediterranean. For empathy, the differences are between tourists coming from the Mediterranean Sea and those coming from Marmara and Black Sea; between the tourists coming from Eastern Anatolia and those from Mediterranean, Central Anatolia, Aegean and Southeast Anatolia. Cultural differences among people living in different regions of Turkey, differences in ways of life, differences about climate and eating habits are effective in their evaluations of service quality.

For example, people living in Black Sea Region are fast, short-tempered, overhasty and they are accustomed to rain, mud and horse-riding. However, it is difficult to observe the same habits in Aegean, Mediterranean, Central Anatolia and Eastern people. 
There are also serious differences between the Eastern people and the Mediterranean people. These differences can also be seen in the assessment of service quality. For foreign tourists; It was determined that there is a difference between tourists coming from America and tourists from Europe and Asia about assurance and empathy. Differences among continents are normal and reasonable in that there are differences among regions within a country. For this reason, it is clear that the determination of the characteristics and expectations of the tourists in terms of their residence is important for customer satisfaction and loyalty. The use of the findings, comments and suggestions of the study in the enterprises performing equestrian trekking activities may enable that the visitors to be more satisfied with the services provided and as a result, the satisfaction level and the number of devoted customers will increase. Education and training of employees are essential in equestrian tourism to ensure quality and customer satisfaction, as well as the safety of horses and guests (Sigurðardóttir \& Helgadóttir, 2015a). Satisfaction questionnaires posted online by Cavaliers du Monde tour operator suggest that clients consider the main criteria that determine the success of a trip are 'the personality and the qualifications of the guide'. Of course, the beauty of the landscape and local cultural and historical heritage are also key factors, but no more so than the quality of the animals, the equipment and the support provided (Pickel-Chevalier, 2015, p.126-127). Therefore, it is believed that the increase in the profitability of the enterprises will increase the economy and the tax revenues of the state will be affected positively by the situation. Moreover, thanks to these activities with high service quality, it will be possible to contribute to both local and international promotion.

In addition, it is known that one of the activities that cause the least harm to nature is the equestrian trekking among the touristic activities in Nevşehir (hot air balloon tours, ATV tours, regional tours with buses). For this reason, it is believed that the increase in service quality of the enterprises carrying out equestrian trekking will benefit from both economic and ecological aspects.

It is thought that this study will guide the future studies.

\section{Acknowledgements}

The authors would like to thank to equestrian walks establishments in Core Cappadocia and participants of the survey.

\section{REFERENCES}

Aydoğdu, A., \& Tanrısever, C. (2015). Turizmde Atlı Spor Kümelenmesi: Daday Örneği (Riding as a Cluster in Tourism: Case of Daday). Doğu Karadeniz Bölgesi Sürdürülebilir Turizm Kongresi, 14-16 Mayıs, Gümüşhane, p. $286-300$.

Batman, O., \& Eraslan, H. (2007). Spor Turizmi (Sport Tourism). In Sürdürülebilir Rekabet Avantajı Elde Etmede Turizm Sektörü - Sektörel Stratejiler ve Uygulamalar (Tourism Sector in Achieving Sustainable Competitive Advantage - Sectoral Strategies and Practices), p.197-220, Ed.: Bulu, M. and Eraslan, H., Uluslararası Rekabet Araştırmaları Kurumu Derneği Yayınları Yayın No: 2007/1, Kazancı Matbaacılık, İstanbul.

Belber, B.G. (2018). Ekoturizmde Pazarlama Çabaları ve Turist Davranışları (Marketing Efforts and Tourist Behavior in Ecotourism). Detay Yayıncılı, Ankara.

Buchmann, A. (2017). Insights into domestic horse tourism: The case study of Lake Macquarie, NSW, Australia. Current Issues in Tourism, 20(3), p. 261-277.

Burns, A.C., \& Bush, R.F. (2014). Marketing Research, Pearson Education, USA, 7th ed.

Çimen, H., \& Abacı, Z.T. (2012). Preferred Rural Tourism Cultivars: The Case of Ardahan Vocational School. International Journal of Social and Economic Sciences, (2), p. 1-4.

Genç, K., \& Şengül, S. (2016). Journey to the Beautiful Horses Country: An Evaluation of High-Income Tourist Attraction to the Cappadocia Region, $2^{\text {nd }}$ International Nevşehir History and Culture Symposium, p. 878-891. 
Assessments as Regard of Service Quality of Touristic Consumers Who Participate in Equestrian Trekking Activities: An Application in Core Cappadocia, Turkey

Güngör, Ş. (2016). Use of Horse in Creating Alternative Tourism Activities and Product Range: A Nevşehir Case. International Journal of Eurasia Social Sciences, Vol. 7, No. 22, p. 81-99.

Gürbüz, S. \& Şahin, F. (2015). Sosyal Bilimlerde Araştırma Yöntemleri Felsefe - Yöntem - Analiz (Research Methods in Social Sciences Philosophy - Method - Analysis), Seçkin Yayıncılık, Ankara.

Hacıŏlu, N. \& Avcıkurt, C. (2011). Turistik Urün Çeşitlendirmesi, (Touristic Product Diversification), Nobel Yayınevi, Ankara.

Helgadottir, G., \& Sigurðardottir, I. (2004). Rekstrarkönnun meðal hestaleiga og hestaferðafyrirtækja a İslandi.

Helgadóttir, G. (2006). The culture of horsemanship and horse-based tourism in Iceland. Current Issues in Tourism, 9(6), p. 535-548.

Helgadóttir, G., \& Sigurðardóttir, I. (2008). Horse-based tourism: Community, quality and disinterest in economic value. Scandinavian Journal of Hospitality and Tourism, 8(2), p. 105-121.

Jasiñski, N., Prus K., \& Piêta W. (2006). Equestrian tourism on the Kraków-Czêstochowa Upland. In D. Dudkiewicz, F. Midura \& E. Wysocka (Eds.), Tourism and recreation as a factor increasing the attractiveness and competitiveness of the region, Warszawa: Almamer Wyzsza Szkola Ekonomiczna. (in Polish) p. 427-435.

Kiper, T., \& Yllmaz, E. (2008). The Possibility of Tourism Activities That Support Rural Development between Şarköy and Kumbağ and the Role of Local People. Journal of Tekirdag Agricultural Faculty, 5 (2), p. 159-168.

Kline, C. S., Cardenas, D., Viren, P. P., \& Swanson, J. R. (2015). Using a community tourism development model to explore equestrian trail tourism potential in Virginia. Journal of Destination Marketing \& Management, 4(2), p. 79-87.

Meydan Uygur, S. (2007). Turizm Pazarlaması, (Tourism Marketing), Nobel Yayın Dağıtım, Ankara.

Notzke, C. (2017), Equestrian tourism: animal agency observed, Current Issues in Tourism, DOI: 10.1080/13683500.2017.1349081, p. 1-19.

Ollenburg, C. (2005), Worldwide structure of the equestrian tourism sector. Journal of Ecotourism, 4 (1), p. 47-55.

Oruç, O. (2004). Studying the nature-horse sports tourism as an alternative tourism kind at Kastamonu sample, Unpublished Master Thesis, Ylldız Technical University Social Sciences Enstitutation. İstanbul.

Özveren, Y.S. (2010). Müssteri Memnuniyeti ve Hizmet Kalitesi İlişkileri: Mersin İlindeki 4 ve 5 Ylldılı Oteller Örneği, (The Relationships of Service Quality and Customer Satisfaction: An Example 4 and 5 Star Hotels in Mersin), Unpublished Master Thesis, Mersin Üniversitesi

Parasuraman, A., Zeithaml, V.A., \& Berry, L.L., (1988). SERVQUAL: A Multiple-Item Scale for Measuring Consumer Perceptions of Service Quality. Journal of Retailing, 64 (1), p. 12-40.

Pickel-Chevalier, S. (2015). Can equestrian tourism be a solution for sustainable tourism development in France? Loisir et Société / Society and Leisure, 38 (1), p. 110-134.

Rızaoğlu, B. (2003). Turizm Davranışı (Tourism Behavior), Detay Yayıncılı, Ankara.

Sigurðardóttir, I. (2015). Identifying the success criteria of Icelandic horse-based tourism businesses: Interviews with operators, Cheval, Tourisme \& Sociétés/Horse, Tourism \& Societies, Mondes du Tourisme, Special Issue - Hors Série, Juin, 2015, p. 150-160.

Sigurðardóttir, I., \& Helgadóttir, G. (2015a). Riding high: Quality and customer satisfaction in equestrian tourism in Iceland. Scandinavian Journal of Hospitality and Tourism, 15 (1-2), p. 105-121

Swarbrooke, J., \& Horner, S. (2004). Consumer Behaviour in Tourism, Martins the Printers, Oxford.

Swarbrooke, J., Beard, C., Leckie, S., \& Pomfret, G. (2003). The Adventure Tourism The New Frontier, Butterworth-Heinemann, Oxford, UK.

Tucker, H., \& Emge, A. (2010). Managing a World Heritage Site: The Case of Cappadocia. Anatolia: An International Journal of Tourism and Hospitality Research, 21 (1), p. 1-14.

Ünver, A.F. (2006). Çağdan modern olimpiyatlara binicilik sporu ve Türk biniciliğ̈inin olimpik gelişimi, (Equestrian sport from ancient world to modern Olympics and Olympic development of Turkish equestrianism), Ankara Gazi University, Educational Sciences Enstitutation Unpublished PhD Thesis, Ankara.

Ünver, A. F. (2003). The effects of correct seat and aids to the improuement feeling of riding in equestrian sport, Gazi University Health Sciences Institute, Unpublished Master Thesis, Ankara.

Yamane, T. (2001). Temel Örnekleme Yöntemleri, (Basic Sampling Methods), Translator: Esin, A., Bakır, M.A., Aydın, C. ve Gürbüzsel, E., Literatür Yayıncillk, İstanbul.

*** Kapadokya'da Turizm Yatırımı Olanakları, (Tourism Investment Opportunities in Cappadocia), Ahiler Kalkınma Ajansı,ahika.gov.tr/assets/ilgilidosyalar/Kapadokya-Turizm-Yatirim-Olanaklari.pdf, accessed 24.10.2018.

Submitted:

09.11.2018
Revised:

25.01.2019
Accepted and published online 29.01.2019 